\title{
DESVELANDO A CONCEPÇÃO DE ADOLESCÊNCIA ADOLESCENTE PRESENTE NO DISCURSO DA SAÚDE PÚBLICA
}

\author{
Fumika Peres* \\ Cornélio P. Rosenburg**
}

\begin{abstract}
Resumo: Este artigo é parte de uma Tese de Doutorado***. Trata-se de um trabalho de natureza teórica que, no campo das Ciências Sociais, busca analisar criticamente o conhecimento produzido e utilizado na área da saúde e que vem orientando a prática com adolescentes, de forma hegemônica, desvelando a concepção de adolescência/adolescente presente no discurso da Saúde Pública. Mediante um processo de desconstrução e reconstrução histórica do discurso em estudo, utilizando-se o instrumental de pesquisa em História Social, reconhece-se a concepção adotada, representativa do paradigma médico-biológi$\mathrm{co} /$ biomédico, que vem orientando, de forma predominante, a produção do conhecimento e as práticas correspondentes nessa área de atuação.
\end{abstract}

Palavras-chave: adolescente/adolescência; Saúde Pública; análise de discurso; ciências sociais

* Professor Doutor do Departamento de Saúde Materno-Infantil da Faculdade de Saúde Pública da USP. E-mail fmk@usp.br

** Professor Associado do Departamento de Saúde Materno-Infantil da Faculdade de Saúde Pública da USP

*** PERES, F. Adolescência: em busca dos sujeitos sociais. São Paulo, 1995. [Tese de Doutorado, Faculdade de Saúde Pública, Universidade de São Paulo] 


\section{INTRODUÇÃO}

O final da década dos 80 e início dos 90 presenciam, na América Latina e Caribe, o movimento de maior visibilidade no campo da Saúde Pública, no sentido de implementar e implantar ações de saúde voltadas ao grupo adolescente, sob o patrocínio e cooperação técnica da Organização Panamericana de Saúde - OPS - e Fundação Kellogg. Até então, o trabalho com adolescentes vinha sendo desenvolvido em alguns locais, estados, por iniciativas localizadas e não como parte de uma política nacional, inserida num esforço internacional de abranger um grupo de países, no caso, a América Latina e Caribe.

Este estudo propõe-se a reconhecer a concepção de adolescência/adolescente presente no discurso que norteou esse movimento, na medida em que o mesmo traz, em seu bojo, todo um ideário acerca de adolescência/adolescente e saúde, como objeto de uma Política Internacional de Saúde.

Dentre as inúmeras questões de natureza teórica a respeito de Saúde Integral do Adolescente, a primeira a que somos remetidos, refere-se a: do quê, de quem estamos falando? Esta apresenta-se como ponto de partida fundamental, para tentar sistematizar o nosso pensar sobre a adolescência, mais particularmente sobre o processo de produção de conhecimento nessa área e suas repercussões na criação/ (re)criação/ (re)produção de práticas concretas, sobretudo no quadro das políticas públicas de saúde.

Essa primeira questão já permite dar uma idéia da complexidade do tema, pois implica, antes de mais nada, ter uma compreensão da adolescência como fenômeno existencial, e como tal, é falar de algo que afeta a cada um de nós. Isto significa que não se trata de um objeto de estudo, exterior ao sujeito pesquisador, passível de uma abordagem "objetivista", segundo as regras dominantes para a construção de um conhecimento dito "científico".

Reconhecer, pois, que o sujeito cognoscente não é neutro ao estudar questões que dizem respeito à vida/existência humana, no nosso caso particular, estudar a Adolescência quer dizer: assumirmos concretamente a necessidade de nos expormos, sabendo, de antemão, que-o nosso olhar face ao nosso objeto estará marcado pelo significado de nossa experiência vivida e refletida. Para esta tarefa, assumimos pressupostos teórico-metodológicos, sustentados por determinados ramos do conhecimento, nos quais nos apoiaremos para triIhar um caminho sujeito a percalços, surpresas, incertezas e inseguranças, pois que estaremos transitando num reino de dúvidas, questionamentos e, portanto, de crítica.

Os pressupostos que subjazem à nossa leitura são distintos daqueles que partem da noção de que o processo adolescente é universal, e, portanto, natural, imanente ao pro- 
cesso de desenvolvimento humano, descaracterizando, assim, a existência humana como categoria histórico-social. Nesta perspectiva, foi possível levantar uma série de questões/ dúvidas acerca das concepções veiculadas na área da saúde, em particular, que tendem a universalizar/naturalizar/padronizar o processo, segundo parâmetros pré-estabelecidos, desconsiderando os fatos vividos e seus significados que marcam/particularizam o processo de individuação ou de individualização de sujeitos concretos, assim como as possibilidades diferenciais/desiguais que a sociedade cria para a travessia da infância para a condição de adulto para os distintos grupos sociais.

O nosso modo de olhar, de fazer a leitura da realidade, rompe com a concepção cientificista acerca da relação: sujeito-objeto, da falsa oposição entre ambos - a crença na neutralidade do sujeito do conhecimento - daí, a preocupação em utilizar instrumentos teórico-metodológicos e técnicos coerentes que possibilitassem acercarmo-nos da realidade que desejamos conhecer/desvendar. Esta é a conseqüência de nossa opção de mergulhar na questão da adolescência, enquanto experiência humana, portanto parte de um processo contraditório, que não tem um sentido único, não é homogêneo, nem tampouco linear e, muito menos, com um único significado, pois que é dependente das condições materiais/objetivas e subjetivas de existência de sujeitos reais.

Inicialmente, é fundamental definir o objeto de nosso trabalho - seria a Adolescência ou Adolescentes? ou ambos? Quais as implicações dessa definição?

Esta é uma questão que costuma ficar no "limbo", em termos da literatura, não no sentido voluntário, premeditado, mas porque, acreditamos, salvo engano, poucos pararam para refletir a respeito. $E$, ao não fazê-lo, não explicitá-lo, em muitos momentos, tende-se a reduzir a compreensão da adolescência ao que se observa em determinados adolescentes, generalizando o observado em seres particulares, singulares, ao universo dos adolescentes e, destes à concepção de adolescência. Tais generalizações, de um lado, levam muitos a "naturalizarem" o processo da Adolescência e, desta feita, dificultando identificar diferenças e desigualdades em adolescentes concretos e, por outro lado, a realidade, não correspondendo a tais generalizações, pelo fato de não constituir um único bloco homogêneo, ao contrário, ser constitutivamente heterogênea, eivada de contradições, desigualdades e diferenças, leva outros até à possibilidade extrema de questionarem a própria existência do processo, pelo menos em alguns grupos sociais ou em culturas específicas, no sentido instituído.

Com o intuito de dar maior consistência a este tipo de colocação, apresentamos, sucintamente, o que é encontrado na literatura a esse respeito e que pode ser mais esclarecedor que a nossa simples interpretação. 
Dentre aqueles que partilham da tendência a naturalizar o processo da adolescência, conferindo-Ihe um caráter universalizante, podemos visualizar notadamente o grupo de estudiosos que aborda a questão, a partir do paradigma biomédico (ou médicobiológico). Segundo esta tendência, a adolescência é considerada uma etapa de transição entre a infância e a idade adulta, tendo como base as transformações puberais, de caráter biológico, que, por sua vez, desencadeariam mudanças psicológicas e sociais, até atingir a maturidade. Esta etapa do desenvolvimento humano corresponde, para a maioria daqueles que integram essa tendência, à segunda década da vida, ou seja, dos 10 aos 20 anos, sendo considerados adolescentes todos aqueles que se situarem no referido grupo etário.

Tal tendência, muito marcante na área da Saúde, faz sentido, na medida em que a abordagem da questão tem suas raízes na medicina do adolescente. A esse respeito, AYRES, 1990, dá sua contribuição relevante, ao destacar que:

"...embora os trabalhos científicos sobre a adolescência apontem seu caráter histórico, os textos médicos sobre a saúde do adolescente e sobre as características das práticas para ela voltadas revelam uniformidade surpreendente. São unânimes as referências a um padrão "típico" de Adolescente, em termos de suas necessidades de saúde e das formas de relação deste com os serviços, de forma geral...

A adolescência, como objeto do discurso médico, reveste-se nestes textos, de caráter a-histórico, assim como a natureza da intervenção a ela dirigida. Ela é traduzida como um estágio do desenvolvimento humano, identificado em todo e cada indivíduo, estágio esse que traz em si mesmo significados específicos.."

O autor mencionado atribui a natureza a-histórica conferida à adolescência como sendo expressão de uma característica histórica da medicina e não uma propriedade intrínseca da adolescência, enquanto objeto, nisto não diferindo de outras dimensões da existência humana que ela (medicina) toma para estudo e intervenção. Nessa linha, a medicina de adolescentes, embora incorpore elementos de outros ramos do conhecimento, distintos em termos de seus pressupostos teórico-metodológicos, como a psicologia, a sociologia e a antropologia, ao definir a adolescência, faz a síntese desses elementos, no seu específico objeto, através da universalidade fenomênica e da singularidade interpretativa desses fenômenos que têm caracterizado o conjunto da produção de conhecimentos e cuidados médicos instrumentalizados pela Clínica, de modo geral. Em outros termos, os demais aspectos são subordinados à dimensão somática, já que é em torno desta que se organizará a apreensão dos demais. 
Referindo-se aos aspectos psicológicos, Ayres apresenta a seguinte análise:

“....Embora secundarizadas em relação ao somático pelo aspecto metodológico apontado, os aspectos psicológicos também se configuram, mesmo nos textos de clínica geral, como outro importante campo de problematizações para a medicina de adolescentes. Aqui, mais uma vez transparece o binômio universalização-individualização, seja nas teorias elaboradas sobre o status psico-emocional do adolescente, seja nas transposições dessas teorias para o campo das práticas. São numerosas as teorias psicológicas que se referem a uma síndrome da adolescência."

De imediato o termo síndrome já nos remete à idéia de uma descrição fenomenológica típica, no caso aqui, decorrência específica da condição adolescente. Essas teorias, embora apresentem alguma diversidade entre si, têm um núcleo interpretativo comum: o indivíduo se vê diante de uma condição inédita de sua experiência, seja pelas condições objetivas de sua existência, seja pela percepção diferenciada que delas alcança. Diante desse ineditismo surgem, então, as reações típicas, que podem ou não configurar problemas, modulados pelos diversos fatores que interferem com a psiquê humana. Será individual, assim, a identificação empírica da síndrome, embora as categorias utilizadas para isto se construam a partir de uma ótica generalizante. (p.147)

Quanto à dimensão social da adolescência, situada, segundo o autor, na base das definições clássicas, já que todas destacam a abrangência dos aspectos sociais que caracterizam a transição adolescente, esta, entretanto, ao se incorporar no modelo clínico, sofre um processo de naturalização, operado pela reificação da adolescência na forma de um status próprio de todo um segmento etário da sociedade, de uma cultura adolescente, objetivada por meio de uma psico-sociologia do adolescente. Desse modo, certos comportamentos observados nesse segmento são tomados como expressão das condições objetivas de vida a que estariam submetidos seus portadores; são encarados como resultantes previsiveis do pensar e agir frente a tais condições. Em outras palavras, os jovens enfrentariam determinadas situações, pelo fato de serem jovens, que explicariam, ao menos em parte, seu comportamento.

Tendo como referencial teórico as ciências sociais, encontramos um outro grupo, enquanto tendência, que considera a adolescência e juventude como categoria sóciocultural, de origem histórica, destituída do sentido de universalidade atribuída pelo grupo anterior. CAVALCANTI, 1988, afirma que a puberdade é um conceito biológico, enquanto adolescência é um conceito sociológico. (p.9) Na preocupação de reconstituir a sóciogênese da adolescência, o autor assim se expressa: 
"Olhando para o passado se evidencia, com surpresa, que há pouco mais de 300 anos, ninguém fazia a menor menção ao período de vida que hoje chamamos adolescência. O próprio conceito de infância era muito vago na antigüidade e, só no final da ldade Média, com o aparecimento dos comerciantes como segmento de força social numérica $e$ qualitativamente importante, é que a infância se caracterizou como um período de vida diferente da idade adulta...(p. 9)

"...Nesse sentido, enquanto que a sócio-gênese da infância está ligada à história da burguesia, a sócio-gênese da adolescência é, em termos históricos, um acontecimento relativamente recente. Tem-se falado que a adolescência é uma invenção social que teve lugar a partir do século XVIII. Em épocas anteriores, o indivíduo saía da infância diretamente para a idade adulta, sem nenhum período intermediário. Se a infância nasceu com a burguesia, a adolescência foi gerada no bojo da revolução industrial. Seu conceito é mais nítido na população urbana do que na população do campo e bem mais caracterizado quanto maior for o privilégio da classe social a que pertence...(p.10)

Esta visão é compartilhada por outros autores, dentre eles, CASTELLAR, 1989, para quem a puberdade ganhou um conceito puramente biológico, enquanto adolescência passa a significar conceito psicológico e social....Prosseguindo, o autor afirma:

"Em realidade, não existe uma adolescência, mas sim, Adolescências, em função do político, do social, do cultural e do momento em que estará inserido o adolescente...."

SALTALAMACCHIA, 1990, chama atenção para a análise da concepção de adolescência dentro do marco sócio-cultural, lembrando que as categorias utilizadas pela vertente anterior são carregadas de significados, não se tratando de "verdades universais", como são apresentadas. Assim, por exemplo, sustenta que:

“(...) en la definición de las categorias de edad, siempre se encuentran implícitos importantes contenidos socio-culturales. Debido a ello, lo que en cada cultura se ha definido como niñez, adolescencia, juventud, adultez y/o vejez, ha sufrido importantes variaciones. Y lo mismo ha ocurrido con los roles sociales que les son asignados. De alli que, en la indagación sobre conceptos relativos a cuestiones etáreas sea indispensable incluir conceptos de la aún no muy difundida, pero a todas luces necesária, sociologia de las edades o de las generaciones. Esto es: el relacionar la edad tanto con sus significaciones socio-culturales más generales como con aquellas otras significaciones que, en el interior de cada pais, determinan cuales son las maneras en que cada cohorte se relaciona con todo el acontecer social...(p.4 e 5.) 
Prosseguindo em suas considerações, dialoga com os integrantes da primeira tendência apresentada, propondo a definição dos termos, conforme segue:

"Aunque siempre será falsa la creencia de que no hay diferencias en las formas en que se produce la transición bio-psicológica entre la niñez y la edad adulta, el aspecto bio-psicológico es, en todo caso, el único aspecto en el que se puede encontrar cierta comunidad entre diferentes culturas. $Y$ entonces, ¿Por qué no utilizar los conceptos de pubescencia y pubertad - en lugar de adolescencia, que contiene intensas determinaciones histórico-culturales - para denominar esa fase de la vida humana? $Y$, en todo caso, por qué no llamar rituales de pasaje a ese conjunto de actos culturales mediante los cuales, en culturas recolectoras y/o casadoras, se señala el paso hacia las responsabilidades y derechos que le corresponden a los adultos en cada una de esas sociedades?"

TORRES-RIVAS, 1989, ao analisar a questão em seis países da América Latina, em uma de suas passagens refere-se à determinação social da adolescência/juventude da seguinte forma:

"La sociedad cuando se desarrolla - es decir cuando crece y se diferencia hacia adentro - tiende a prolongar el ciclo de transición entre la infancia y la vida adulta. Ello se produce de múltiples formas, sin posibilidad de encontrar modelo alguno, en funcción de la história y la cultura particulares de los diferentes agrupamientos humanos. En general, sin embargo, se puede decir que las culturas de base campesina, comprimen la transición porque se preparan desde la temprana edad para enfrentar responsabilidades y tareas. El ciclo es breve y la juventud (adolescencia) no aparece salvo que se le mida con manía estadística y con fobia por la história."(p.9)

Outros autores poderiam estar sendo referidos neste grupo, sobretudo aqueles que assumem, como ponto de partida, o estudo da juventude, ao invés de adolescência, mas tendo-a como essa etapa de transição entre a infância e a idade adulta. Não parece tratar-se apenas de questão semântica o uso de um ou outro termo, mas muito mais relacionada a referencial teórico: de um lado o da biologia e o da psicologia e, de outro, mais claramente, o da sociologia. Nesse sentido, VICUÑA, 1977, apoiando-se no Informe de um grupo de trabalho da OPS sobre Las necesidades de salud de la juventud en América Latina y Caribe, de dezembro de 1975, fornece pistas ao afirmar que:

"Existe um consenso geral de que o termo adolescência refere-se muito mais a um processo de maturidade biológica que transcende à área psico-social e constitui um período durante o qual se inicia e se trata de aperfeiçoar a personalidade, o sentido da 
identidade, a capacidade de abstração e a adaptação harmônica ao meio social... Por outro lado, a juventude é uma categoria fundamentalmente sociológica, em que as pessoas passam a fazer parte da sociedade, com plenitude de direitos e responsabilidades (transcorre entre os 15 e os 25 anos). Para identificar melhor as aparentes divergências conceituais, é necessário destacar que o termo ADOLESCÊNCIA aparece mais ligado à prática médica e da saúde, enquanto que o conceito de JUVENTUDE se refere muito mais ao cumprimento da etapa de integração social da pessoa".

Ligada à questão acima, está implícita a discussão da articulação biológicosocial e a do indivíduo-sociedade, que exige um estudo mais aprofundado, do ponto de vista epistemológico, de grande importância, porém que merece uma investigação específica e que, por isso, será objeto de referência na análise da produção do conhecimento em saúde sobre adolescência apenas no nível necessário para a compreensão do mesmo.

Nesses últimos anos, e, mais especificamente, a partir de fíns da década dos oitenta, estamos observando esforços interdisciplinares, ainda que incipientes, no sentido de analisar criticamente a construção social do conhecimento sobre adolescência e adolescente na área da saúde, com vistas a lograr a apreensão da questão como totalidade concreta, historicamente constituída, articulando as várias dimensões (biológica, psicológica e sóciocultural) e níveis (individual/singular, particular e sociedade) que envolve. Nossa identificação com esta vertente faz com que tenhamos que encarar este desafio dentro de nossas limitações, de vez que temos consciência de que esta tarefa, mais do que um empreendimento interdisciplinar, requer a construção de um conhecimento transdisciplinar, como decorrência da análise crítica proposta, que tem, como pressuposto, que a justaposição de conhecimentos fragmentados de diferentes disciplinas não assegura recuperar essa totalidade buscada. Essa construção, sem dúvida, não será objeto deste trabalho, porém será a direção para a qual tentaremos encaminhar as nossas reflexões, ainda que modestas e limitadas, sempre na busca de um referencial teórico-metodológico que dê conta da reconstituição do nosso objeto de estudo, no caso, a adolescência/adolescentes concretos.

Com esse tipo de preocupação, CAVALCANTI, 1988, inicia as considerações sobre o conceito de adolescência com uma afirmação de Freud: "só vemos a estrutura de um cristal quando ele se quebra...", para dizer que:

"A adolescência, como tudo o que é humano, só pode ser realmente compreendida se fizermos um estudo dos diversos elementos estruturais que entram na composição do ser e do viver do homem. Isso implica na apreciação do biológico, do sociológico e do psicológico que, de modo interdependente e integrado, constituem o cerne da natureza 
humana. Quando não existe uma prévia convicção de que só o conjunto constitui o humano, há a tentação de, na aventura da análise, se deixar perder no encanto do pormenor e se apagar a perspectiva do homem como um ser global. (p.2)... Ao estudar a adolescência, tem que se ter, necessariamente, uma visão de síntese que reúna as peças da análise humana na recomposição do homem total. ...(p.6)"

Conforme referência feita anteriormente, a distinção dos termos Adolescência e Adolescente é importante para início de qualquer discussão, porque o seu uso indiscriminado traz dificuldades de compreensão, uma vez que o primeiro remete ao processo de desenvolvimento humano, enquanto o outro se refere ao sujeito que vivencia essa fase do processo. Isso não quer dizer que constituam duas entidades distintas, que possam ser abordadas como objetos de estudo independentes. Ao contrário, quando conceituamos Adolescência de uma determinada maneira, temos presente uma visão de adolescente, cujas características básicas encontram sua correspondência no conceito emitido ou assumido, da mesma forma que, quando atuamos com adolescentes, implicitamente carregamos uma concepção de adolescência, que se expressa no tipo de relação que com eles estabelecemos, no modo de trabalhar as questões a eles relacionadas, e, fundamentalmente, na direção imprimida ao processo.

Embora essa questão pareça óbvia e elementar para muitos, para outros tem sido motivo de equívocos, nem sempre sem prejuízos no plano da intervenção, razão pela qual a assumimos como ponto de partida para a nossa reflexão.

Imediatamente relacionada ao anterior, necessariamente veio à tona o que se vem entendendo por Adolescência, ou seja, que concepções de adolescência estão presentes na área da saúde e qual é o significado de cada uma delas no nível das práticas?

As concepções de adolescência que até agora expusemos dão idéia das diferentes visões existentes, presentes na literatura. Tendo em vista reconhecer qual dessas visões prevalece na área da Saúde, utilizamos a categoria conceitual de "paradigma", adotada por Thomas KUHN, 1992, entendido, ao mesmo tempo, como "matriz disciplinar" e "realizações concretas de natureza exemplar", por se tratar de termo de uso corrente em várias áreas científicas, inclusive na Saúde, não obstante as diferentes interpretações geradas por seu conceito, fato este reconhecido pelo próprio autor, em posfácio da própria obra de edições mais recentes. Segundo o próprio autor, o termo "paradigma" é usado em dois sentidos diferentes na maior parte do livro:

"De um lado, indica toda a constelação de crenças, valores, técnicas, etc..., compartilhadas pelos membros de uma comunidade determinada. De outro, denota um tipo de 
elemento dessa constelação: as soluções concretas de quebra-cabeças que, empregadas como modelos ou exemplos, podem substituir regras explícitas como base para a solução dos restantes quebra-cabeças da ciência normal"...(p.218)

Tal escolha se deve ao pressuposto de KUHN (1992), que rompe com a concepção de uma evolução unívoca e cumulativa da produção de conhecimentos científicos, definindo o desenvolvimento científico como "uma sucessão de períodos ligados à tradição e pontuados por rupturas não cumulativas" (p.255). Neste sentido, a concepção paradigmática de Kuhn permite distinguir o desenvolvimento científico "normal" - aquele que se limita a aprofundare expandir um conjunto de concepções, instrumentos e valores científicos socialmente legitimados - daqueles que, motivados por insuficiências e inconsistências de ordem estritamente científica ou não, evidenciadas no interior dessa práxis, passa a criar novas concepções e práticas. Permite, assim, relativizar a concepção de "verdade científica" como sinônimo de "verdade absoluta", passando a considerá-la como verdade transitória, tomando o conhecimento como uma obra inacabada, em construção permanente.

\section{RECONHECENDO O PARADIGMA QUE VEM ORIENTANDO, DE FORMA PREDOMI- NANTE, A PRODUÇÃO CIENTÍFICA SOBRE ADOLESCÊNCIA, NA ÁREA DA SAÚDE}

Cabe, agora, reconhecer o paradigma que na área da Saúde vêm orientando de forma predominante a produção científica sobre adolescência, no contexto de sua emergência como objeto da Saúde Pública, com vistas a melhor entender as suas relações com o projeto social a que se vincula, a partir da articulação entre a teoria e prática correspondente.

Tanto a literatura, quanto as justificativas teóricas e o desenho/delineamento das práticas de intervenção na área da Saúde revelam claramente o predomínio e o grande peso da matriz biologicista na formulação ou adoção de conceitos e práticas correspondentes, inclusive no que diz respeito à adolescência/adolescentes. Denominamos essa matriz como paradigma biomédico ou médico/biológico, conforme já mencionamos anteriormente.

Segundo este paradigma, a "adolescência" é descrita como uma fase do desenvolvimento humano, pela qual todos passam, e que corresponde à fase de transição entre a infância e a idade adulta, ocorrendo na segunda década da vida (entre os dez e os vinte anos de idade); caracteriza-se por transformações biológicas, ligadas à puberdade, que transcendem às esferas psicológica e social em direção à maturidade bio-psico-social; constitui um período "crítico," crucial na vida dos indivíduos, por se tratar de momento de definições de "identidade" - sexual, profissional, de valores, etc.-, que gera "crises" que beiram ao patológico, chegando a merecer, por parte de determinados autores da área da "psi", a caracterização de um quadro "típico" da adolescência, como inerente a ela, conhecido como "síndrome 
da adolescência normal". Adolescente é entendido como todo indivíduo que se encontra na faixa etária de dez a vinte anos, que necessariamente passa pelas crises descritas, em busca da maturidade, ou da "identidade", usando as palavras dos autores desta vertente.

Universalizada e naturalizada a adolescência neste tipo de concepção, ainda que reconhecendo o componente social, os adeptos de tal paradigma, ao se depararem com adolescentes concretos, têm o seu olhar direcionado, de antemão, segundo um "padrão" de adolescente, que corre o "risco de se perder" pelas "crises" que enfrenta nesse período e, portanto, pela situação de fragilidade em que se encontra - o substrato da vulnerabilidade -, na linguagem epidemiológica. A necessidade de definição de seu projeto de vida, de adoção de valores e assunção de responsabilidades é tida como situação que gera inseguranças, questionamentos, rebeldia nos sujeitos frente aos valores do "mundo adulto" (quer dizer: sociedade). Neste sentido, a Organização Mundial da Saúde (OMS), em seu relatório dos Debates Técnicos sobre a Saúde dos Jovens, da 42ª. Assembléia Mundial de Saúde, 1989, em sua Introdução, explicita a imagem acima, assinalando que:

"...A adolescência é sempre um período de transição, no qual os jovens desenvolvem suas capacidades experimentando novos tipos de comportamento. Ela representa uma encruzilhada na vida, em que um caminho saudável para a fase adulta poderá ser alcançado se suas necessidades de desenvolvimento e segurança forem atendidas, caso contrário um padrão de comportamento nocivo poderá desenvolver-se com conseqüências negativas para a saúde e sobrevivência, a curto ou longo prazo."(p.3)

HAMBURG \& HAMBURG, 1976, já haviam enfatizado essa idéia, referindo-se à adolescência como:

"Etapa crucial para a formação de hábitos de conduta e comportamentos sociais. Os hábitos que se adquirem nessa idade podem ter uma importância-chave na vida futura dos adolescentes e permitir-lhes, ou impedí-los, um pleno aproveitamento de seu potencial..."

Esta concepção de adolescência é típica, decorrente de um olhar de sobrevôo de um observador impessoal, que mantém uma relação de exterioridade face ao objeto, na figura do especialista - representante do "saber" que, por suas afirmações, traz a garantia da existência de uma ordem, atual ou virtual, como diria CHAUÍ, 1987.

“(....) tal tipo de discurso tende sempre para o anonimato ou para a neutralidade, a fim de testemunhar uma verdade que estaria inscrita nas próprias coisas, como algo posto diante de nós, como racional em sie por sí, ocultando a particularidade numa universalidade abstrata". Quer dizer: é um discurso ideológico, que procura neutralizar o perigo da história, ou seja, que opera no sentido de impedir a percepção da história."(Chaui, 1981). 
Tornamos nossa leitura/interpretação o pensamento de CHAUI, 1981 e 1987, em decorrência da análise de algumas noções/afirmações contidas na concepção de adolescência/ adolescente dentro do paradigma biomédico/médico biológico, as quais apresentamos abaixo:

$1^{\text {a) }}$ A noção de universalidade do fenômeno da adolescência - fase do desenvolvimento humano, pela qual todos passam e que corresponde à transição entre a infância $e$ a idade adulta, ocorrendo na segunda década da vida.

Essa noção traz implícita a idéia de uma evolução natural do ser humano, linear, independente das condições concretas de sua existência - materiais e simbólicas -, ou seja, um processo que se opera segundo um determinismo pré-estabelecido, imanente ao desenvolvimento humano, apesar dos sujeitos em sua diversidade cultural e desigualdade social. Ora, de que processo estamos falando? Estamos reduzindo a adolescência à sua dimensão apenas biológica (ou psicológica), no sentido filogenético, ou à questão das idades cronológicas/identitárias/ demarcadoras do tempo calendário?

Se estamos nos referindo à adolescência como parte do desenvolvimento humano, em sua totalidade, portanto, comportando as dimensões biológica, psicológica e sócio-cultural, ao universalizá-la não estaremos procedendo a uma equivalência das leis que regem cada uma dessas esferas de constituição do ser humano àquelas (leis) que regem a natureza, abstraindo a existência humana como essência, portanto, não se referindo a um processo que diz respeito a homens reais, situados e datados? Onde e como ficam os achados antropológicos que comprovam a inexistência da adolescência tal como descrita nesta perspectiva - fase de transição conflituosa entre a infância e a idade adulta -, em sociedades e grupos sociais determinados?

A naturalização do processo de desenvolvimento humano pressupõe a idéia de natureza humana, presente não só na área da Saúde, mas também na área da Pedagogia, da Psicologia, como algo inalienável, inerente ao ser humano, uma essência humana que se atualiza, orientado segundo um eixo fundado em cada e todo ser humano, apenas um programa genético/psicogenético que se irá cumprindo ao longo do tempo vital.

Essa idéia seria aceitável, no nosso entender, somente na medida em que igualássemos o processo de desenvolvimento humano ao processo de evolução de qualquer outro ser vivo, que se limita a nascer, crescer, amadurecer, reproduzir e morrer. Isso significa reduzir o ser humano à sua dimensão que o aproxima de outros seres vivos, simplesmente, em lugar de destacar exatamente aquilo que o distingue daqueles. Aliás, não nos parece estarmos distante dessa possibilidade, pois até hoje, na área da saúde, a questão do crescimento é tratada como algo distinto do desenvolvimento humano, a tal ponto que, tanto na literatura, 
como nas universidades, quando se refere ao assunto em questão, "Crescimento e Desenvolvimento Humano" é a denominação de aulas, conferências, publicações. Afinal, se estamos nos referindo a um processo existencial de seres humanos, que se dá como um todo multifacetado, com articulações entre as diferentes facetas que comporta - biológica, psicológica, sócio-cultural -, verificamos duplo movimento de redução nesse caso: redução do processo de desenvolvimento à sua faceta biológica e, dentro desta a concepção de crescimento alheia, distinta, excluída (?) da faceta biológica do desenvolvimento humano. Constatamos aqui, de imediato, a presença flagrante do olhar fragmentado do objeto de estudo, fruto da territorialização desmedida do conhecimento, em particular da saúde, que se expressa em forma de especialidades disciplinares e sub-especialidades disciplinares ("especialidade da especialidade"), característica do conhecimento científico moderno, que reduz o ser humano ao seu corpo, decomposto em elementos constituintes, dicotomizando corpo-mente, razãoafetividade, enfim, vivenciamos um processo de dissecação incessante, distanciando-nos cada vez mais de uma visão total de processos existenciais, que não se dão no vazio, mas sempre em condições concretas, no tempo e num dado espaço social.

Assim, quando se afirma a universalidade do fenômeno "Adolescência", enquanto fase do desenvolvimento humano, a partir de apenas uma de suas facetas - biológica (ou psicológica) -, acreditamos tratar-se de uma visão, no mínimo, equivocada e reducionista da questão, mesmo porque nos indagamos como seria possível analisar o biológico (ou o psicológico) em si mesmo, destacando-o de suas interconexões com outras dimensões/ facetas, visto que o ser humano só existe no social - nasce e se desenvolve a partir das/ nas relações sociais (é socializado) em um dado contexto sócio-histórico. Em síntese, o que queremos dizer, traduz-se nas palavras de KOSIK, 1976: “...a concepção dialética concebe o real como um todo estruturado que se desenvolve e se cria"... (p.43).

Todo o acima não quer dizer que estamos deixando de reconhecer a existência de transformações biológicas e dos significados a elas atribuídos pelos sujeitos que as vivenciam e pela sociedade. Muito pelo contrário, a idéia é a de que não é possível analisálas em si mesmas, como se elas contivessem/correspondessem ao processo de "adolescência" em sua totalidade. CHARLOT, 1986, auxilia a compreensão do que queremos dizer, ao assim sintetizar a questão: "O critério biológico não basta, portanto. Num meio inteiramente socializado, as determinações biológicas tomam um sentido social, sem com isso perder sua significação biológica"... (p.105).

Outra noção relacionada à anterior, implícita na concepção de adolescência que estamos analisando e que fortalece a idéia de universalização/naturalização do desenvolvimento humano e, em particular, da "fase" que ocorre na segunda década da vida, diz respeito à de temporalidade, coerente com a construção discursiva em questão. 
KOSIK, 1976, ao colocar que "existir é ser no tempo"... (p.129) fazem-nos refletir sobre a relatividade de tempos instituídos para demarcação das diferentes "etapas" do desenvolvimento humano, ao relacionarmos com a significação correspondente em diferentes momentos e em distintas sociedades. Para sermos mais claras, isto implica que a noção de temporalidade vital e do significado a ela atribuído, vem-se modificando à medida que a duração da vida, em termos de sociedades ou de grupos sociais determinados, vem se alterando, no sentido de seu prolongamento, seja em função da melhoria da qualidade de vida, seja do avanço do conhecimento e desenvolvimento de tecnologias ou de outros mecanismos disponíveis para tal. Ao mesmo tempo, até dentro de tais sociedades, onde contingentes cada vez maiores conseguem prolongar sua existência, podem estar existindo grupos sociais que estão tendo suas vidas abreviadas, exatamente pela inacessibilidade aos bens/recursos logrados pelo avanço científico e tecnológico. Neste sentido, estar no começo, no meio ou no final da vida, assim como os significados sociais conferidos a cada situação e as condições que a sociedade cria a partir da valorização de todo o processo ou de partes dele, implica entender a existência humana em situações concretas - a sua realidade material e subjetiva/simbólica - e o imaginário social que existe em torno da questão. Isto quer dizer que, certamente em sociedades em que a expectativa de vida não ultrapassa(va) os cinqüenta anos de idade (quer dizer, sociedades em que muitos não conseguem sequer nascer vivos ou chegar ao segundo ano de vida), estabelecer o começo, a ascensão à sua metade, o seu centro e o fim do ciclo vital e o significado atribuído a cada um dos seus pedaços/recortes, assim como as condições sociais correspondentes, foram/são muito diferentes do que se pode dizer/esperar de sociedades avançadas, do ponto de vista sócio-econômico, com a expectativa de vida em torno de oitenta anos, em que se conte com uma qualidade de vida digna, extensiva a toda a população, onde "desenvolver-se" ganha uma outra dimensão, um outro significado em relação à anterior. Os espaços sociais para aqueles que se encontram em cada uma das "etapas" e a delimitação entre elas, comporta certamente outros critérios, no sentido de adequação ao tempo vital real e à significação conferida aos seus diferentes momentos, em contextos sócio-históricos específicos, com decorrências que poderiam implicar, por exemplo, no prolongamento das "fases" intermediárias - "adolescência/juventude", "maturidade", até a invenção de outras "fases", que hoje estão contidas na "velhice"/"terceira idade".

Ao contrário da primeira situação apresentada, em que um sujeito com cinqüenta anos era/é considerado ancião/velho/idoso, no final de seu ciclo vital, aqui, com essa idade, seria considerado um adulto, com plena capacidade produtiva, situado mais para o centro do ciclo vital do que próximo de seu final. 
Ao aplicarmos o mesmo raciocínio com os grupos mais jovens em tais tipos de situação, na primeira, provavelmente, aqueles que conseguissem sobreviver ao nascer, ultrapassando os primeiros anos de vida, tão cedo obtivessem a mínima condição física para exercerem uma atividade, teriam sido inseridos na força de trabalho, na condição de um sujeito produtivo, assumindo responsabilidades sociais (a época da revolução industrial é uma boa ilustração disso, assim como a nossa própria realidade, hoje, ainda que com outras características, é tanto ou mais gritante que aquela), sub-remunerados ou constituindo a força de trabalho familiar; em contrapartida, em sociedades avançadas, do tipo descrito (ou em classes/grupos sociais "privilegiados" de sociedades capitalistas, ainda que periféricas), aqueles mesmos, certamente seriam enquadrados na categoria de "crianças", destinadas a brincarem e a estudarem e a prolongarem a situação de proteção social, adiando-se, cada vez mais, o momento de assunção de responsabilidades sociais. Todas essas questões, que revelam a diversidade de situações possíveis, em que entram em consideração, desigualdades sociais, que geram possibilidades desiguais de viver/existir, diversidades culturais, diferenças sociais e que determinam os diferentes modos de encarar a vida/existência (por conseguinte a questão etária e 0 seu sentido) - impedem-nos de concordarmos com a afirmação de que a adolescência é um fenômeno universal, com um quadro fenomênico "típico", conforme descrito na literatura e amplamente utilizado como "padrão" em práticas sociais, sobretudo no campo da saúde e da educação. Ao contrário, confirma-nos cada vez mais a idéia de que a faixa etária considerada, como constituindo a "adolescência" engloba um grupo heterogêneo de sujeitos, em diferentes condições existenciais, que impossibilitam generalizações que induzem a homogeneizá-lo, apesar deles, forjando, com isso, a idéia de uma igualdade abstrata entre eles, porque inexistente no real; e, ao serem classificados/enquadrados/rotulados/homogeneizados/uniformizados, a partir de um critério arbitrário, regido por regras da ciência moderna - classificatória e intervencionista - , em que os fenômenos sociais são abordados como objetos, equivalentes aos fenômenos da natureza, como exterioridade ao sujeito do conhecimento, incorre-se naquilo que já foi salientado anteriormente, de tornar a história social dos homens uma história natural, que não se aplica a homens concretos, com suas contradições, rupturas, descontinuidades.

Dentro ainda da primeira noção que está sendo analisada, há uma última idéia que desejamos abordar e que se refere ao entendimento da "adolescência" como "transição entre a infância e a idade adulta ("maturidade"). "Ao delimitar o início e o fim dessa transição, segundo o critério cronológico, faz supor que nesse período de tempo demarcado - dos 10 aos 20 anos de idade - o processo de "amadurecimento" se complete como um todo, permitindo deduzir que existe uma equivalência/sincronia dos tempos - biológico, psicológico e social no tempo vital humano -, tempo este inscrito em realidades sociais e individuais/singulares específicas. Esta é uma afirmação contraditória no próprio desenvolvimento do discurso sobre a adolescência 
dentro do paradigma "médico-biológico", que atribui ao alargamento do tempo adolescente/ juvenil, do ponto de vista social, a produção de inúmeros problemas, extrapolando esse tempo demarcatório; como os próprios adeptos desse paradigma reconhecem, as condições reais de existência em sociedades concretas, sobretudo em áreas urbanas de grandes cidades, vêm demonstrando a existência de diferenças/ disparidades entre os tempos biológico, psicológico e social, de forma cada vez mais acentuada, contrariando a suposição implícita no enunciado. Tais noções necessitam, no nosso entender, serem melhor elucidadas, de forma articulada, num esforço inter-intradisciplinar, conectada com a realidade, em lugar de aprofundamento de conhecimentos fragmentados do biológico, do psicológico e do sócio-cultural, estes construídos, predominantemente, segundo as regras da ciência moderna positiva, e sem condições de responderem às questões a partir de suas áreas específicas.

Este é um dos problemas envolvidos no estudo da "Adolescência/adolescentes", que merece um trabalho específico de investigação, ficando apenas registrada a importância de que se reveste, a partir desta breve colocação.

O que fizemos até agora, em relação à discussão da noção de temporalidade, a partir da idéia presente na concepção paradigmática "biomédica" de "Adolescência/Adolescentes" foi revelar os elementos presentes em tal concepção que reduzem o tempo à cronologia, demarcação, destituída de suas significações, descaracterizando o viver/existir humano como fenômeno histórico-social, encobrindo as contradições, desigualdades sociais, como forma de reafirmar uma ordem natural, coerente com o discurso ideológico, conforme acentuou anteriormente CHAUÍ, 1981.

Recorremos a CASTORIADIS, 1982, que apresenta, de forma aprofundada, clara e lúcida, como a temporalidade se manifesta socialmente, mostrando a relação entre a dimensão do tempo de demarcação instituído, que ele denomina de tempo identitário e a dimensão propriamente imaginária, e o tempo da significação e sua importância para cada sociedade, concluindo que "existe, para cada sociedade, o que podemos denominar a qualidade do tempo como tal... e que essa qualidade do tempo como tal, mostra que o tempo instituído jamais pode ser reduzido a seu aspecto identitário, calendário e mensurável" (p.248).

O autor desenvolve a idéia de que cada sociedade apresenta uma temporalidade efetiva, que se revela:

"Como seu modo de fazer, que este é visto em sua profunda relação com a significação do passado e do porvir, indissociável, por sua vez, da significação da realidade (o que já é, ou é adquirido, nada é em relação ao que está para ser ou por alcançar) ou, o que vem a ser o mesmo, com as fundações últimas do que vale e do que não vale", que pode, ou não, 
corresponder ao tempo explicitamente instituído. Prossegue, dizendo: "Se considerarmos agora o tempo explicitamente instituído por cada sociedade, impõe-se imediatamente a distinção entre duas dimensões diferentes e obrigatórias desta instituição, a dimensão identitária e a dimensão propriamente imaginária. $O$ tempo instituído como identitário é o tempo de demarcação, ou tempo das medidas. O tempo instituído como imaginário (socialmente imaginário, entende-se) é o tempo da significação, ou tempo significativo (distinção que não implica de modo algum uma separação do que distinguimos). $O$ tempo instituído como identitário, ou tempo de demarcação, é aquele relativo à medida do tempo ou à imposição ao tempo de uma medida, e como tal, inclui sua segmentação em partes idênticas ou idealmente (e impossivelmente) congruentes. É o tempo calendário, com suas divisões numéricas, em sua maioria apoiadas sobre os fenômenos periódicos do estrato natural (dia, mês, lunar, estações, ano), depois aprimoradas em função de uma elaboração lógico-científica, mas sempre por referência a fenômenos espaciais, mas também por razões que só dizem respeito à sociedade considerada". (p.246)

(...) O tempo instituído como tempo da significação, tempo significativo ou tempo imaginário (social), alerta o autor, mantém com o tempo identitário a relação de inerência recíproca ou de implicação circular que sempre existe entre as duas dimensões de toda instituição social: a dimensão conjuntista identitária e a dimensão da significação. $O$ tempo identitário só é "tempo" porque é referido ao tempo imaginário, que lhe confere sua significação de "tempo"; e o tempo imaginário seria indefinivel, irreferivel, inapreensível - não seria nada fora do tempo identitário. Assim, por exemplo, as articulações do tempo imaginário dobram ou aumentam os marcos numéricos do tempo calendário. O que nele ocorre não é simples acontecimento repetido, mas manifestação essencial da ordem do mundo tal como é instituído pela sociedade considerada, das forças que a animam, dos momentos privilegiados da atividade social - quer diga respeito ao trabalho, aos ritos, às festas, à política..."(p. 247)

Em função dessas colocações, o autor reafirma que, para cada sociedade existe a qualidade do tempo como tal, mostrando que o tempo instituído não pode jamais ser reduzido a seu aspecto puramente identitário, calendário e mensurável. Analisando o que vem ocorrendo nas sociedades ocidentais de capitalismo moderno, onde a tentativa desta redução foi levada mais longe, o autor constata que, aí não só subsiste, e de forma maciça, uma qualidade de fluxo temporal como tal - tempo de "progresso", da "acumulação"- mas que esta redução do tempo em tempo puramente e somente mensurável, é apenas uma manifestação, entre outras, do imaginário dessa sociedade e instrumento de sua materialização.

"É preciso que o tempo só seja isso, puro médium homogêneo neutro, ou o parâmetro " $t$ " de uma família de funções exponenciais, para que haja, como dizem os 
economistas, uma taxa de atualização do futuro, para que tudo pareça como mensurável e calculável, para que a significação imaginária central desta sociedade: a pseudoracionalização possa parecer possuir um mínimo de coerência segundo suas próprias normas “...(p.248)

Com isso, conclui o pensamento, dizendo que "esse exemplo só faz ilustrar, no caso do tempo, uma proposição geral: um tempo instituído como puramente identitário é impossível, porque a separação da organização conjuntista do mundo social e das significações imaginárias sociais é impossível “... (p.248).

À luz das sábias colocações de pensadores como Chauí, Ortega y Gasset, Kosik e Castoriadis, acreditamos ser desnecessário retomar a leitura efetuada da primeira parte da concepção de "adolescência/adolescentes" acerca das noções presentes na visão paradigmática médico-biológica ou biomédica, porém, para fins de nossa própria orientação, no sentido de prosseguirmos na caminhada proposta, sinteticamente vamos assinalar os principais pontos que julgamos importantes:

1. A noção de temporalidade que pudemos apreender corresponde à visão de tempo explicitamente instituído, reduzido à dimensão identitária, de mensuração, de tempo calendário/cronológico, que dissimula/encobre - através da idéia de "desenvolvimento", enquanto história natural/universal/inear da existência humana, no sentido de evolução bio/psicogenética - a verdadeira história social da existência humana, construída segundo a lógica histórica (e não do natural), explicitando processos reais de homens concretos, contraditórios, com continuidades/descontinuidades/rupturas, socializados desde seu nascimento;

2. Ao demarcar a faixa etária de dez aos vinte anos de idade, como o tempo da adolescência, cuja significação é amplamente discutível, concorre/corrobora, desta forma, a idéia de que tal tipo de abordagem ignora as especificidades de sociedades, grupos sociais distintos, encobrindo diferenças e desigualdades sociais de sujeitos reais em seu processo de desenvolvimento; com isso, homogeniza as condições concretas de existência dos mesmos, dentro de uma concepção de "igualdade" abstrata e universal, enquanto possibilidades, para todos aqueles que se encontram na faixa etária dos dez aos vinte anos, não encontrando, portanto, sustentação na realidade que procura representar em seu enunciado.

$2^{a}$ ) Relacionada à anterior, está presente a noção de "Crise" - "A adolescência constitui um período "crítico", crucial na vida dos indivíduos.... "

Como vimos anteriormente, a concepção de desenvolvimento está pautada na 
idéia de evolução natural - de uma essência humana pré/acima do social - que pressupõe que cada indivíduo possui características que são universais, independentes da influência social, em forma de capacidades inerentes/inatas à natureza humana, que vão se expressando em uma seqüência cronológica contínua, que comporta níveis de complexidade crescente e com transições regulares de uma "fase" para outra.

Nesse sentido, o seu curso, na concepção da ciência moderna positiva, exclui a contradição, a tal ponto de se autodenominar de ciência da não-contradição, dada a natureza metafísica do pensar lógico-formal; este nega a contradição enquanto aspecto objetivo da realidade, e, ao assim raciocinar, ela (contradição), é vista como sinônimo de "inverdade", conforme PINTO, 1979. CHAUI, 1987, acrescenta que isso se deve ao fato de a história ser entendida como:

"Continuidade e progresso, excluindo a idéia de ruptura e a diferença temporal - 0 que diferencia internamente presente, passado e futuro - substituindo-a pela diferença empírica dos tempos ou pela sucessão - temporalidade una, única, linear, sucessiva e contínua". (p. 119)

Dessa maneira, segundo a lógica da ordem natural, ordena-se o espaço social, organiza-se a memória e administra-se o porvir, como mecanismo ideológico que, ao encobrir a história, constrói a idéia de que o real é racional; e que essa racionalidade consiste num conjunto de leis universais e necessárias ou de modelos fixos, tornando-se possível pensar a sociedade não como constituída pela divisão originária das classes, mas apenas como, contendo divisões, correspondentes às esferas das chamadas instituições sociais, compondo um todo harmonioso.

A sociedade é então vista como um sistema, com uma série de subsistemas, cada uma delas tendo sua racionalidade própria e, portanto, sua própria objetividade, sua própria transparência, suas próprias leis, sua própria harmonia; e o todo (sociedade) funcionaria graças a uma articulação harmoniosa desses vários subsistemas - é a concepção em que, ao invés do termo contradição, a ideologia utiliza a idéia de "CRISE" para os momentos em que aquelas racionalidades parciais não se articulam harmoniosamente umas com as outras e o todo começa a se mostrar problemático. Essa idéia de "crise", segundo CHAUI, 1980.

"É uma representação graças à qual aparentemente se admitirá o problema e, simultaneamente, poder-se-á dissimulá-lo, uma vez que ela é imaginada como um movimento de irracionalidade que invade a racionalidade, gera desordem e caos e precisa ser conjurada para que a racionalidade anterior, ou outra nova, seja restaurada". (p.36)

Nesse sentido, a noção de "crise", permite dar a idéia de um desarranjo, pois a 
"harmonia" é pressuposta como sendo de direito, reduzindo-a a uma desordem fatual, provocada por enganos, voluntários ou involuntários, dos agentes sociais, ou por mau funcionamento de certas partes do todo.

A "crise" serve, assim, para opor uma ordem ideal a uma desordem real, na qual a norma ou a lei é contrariada pelo acontecimento (portanto, a-historicidade), este encarado como um engano, um acidente, ou algo inadequado, ou seja, como um "desvio".

Em outras palavras, para a autora, crise e desvio são noções que pressupõem um dever ser contrariado pelo acontecer, mas que poderá ser restaurado porque é um dever ser. Há exterioridade entre o acontecimento e o sistema, entre a conjuntura e a estrutura, entre a historicidade e a racionalidade. A noção de crise, assim, ao invés de se apresentar como algo que atesta os limites da representação supostamente objetiva e racional, ideologicamente confirma e reforça a representação, na medida em que nomeia os conflitos no interior da sociedade para melhor escondê-los, servindo de explicação, isto é, como um saber para justificar teoricamente a emergência de um suposto irracional no coração da racionalidade e, ao mesmo tempo, ocultar a crise verdadeira, resultado de contradição - que, na linguagem da crise passam a se chamar perigo.

A crise é usada para que surja diante dos agentes sociais e políticos "o sentimento de um perigo que ameaça igualmente a todos, que dê a eles o sentimento de uma comunidade de interesses e de destino, levando-os a aceitarem a bandeira da salvação de uma sociedade supostamente homogênea, racional, cientificamente transparente" (p.39) seja, através de técnicas racionalizadoras, tecnologias apresentadas como dotadas de "fantástico poder reordenador e racionalizador para combater a irracionalidade, seja reprimindo manifestações das classes populares para fazer frente ao perigo".

Enfim, essa forma de apresentar a noção de crise, faz parte de um discurso, no dizer de CHAUI, 1987, "essencialista, normativo, prescritivo e pedagógico" (p.109).

$\mathrm{Na}$ concepção de adolescência, essa leitura faz sentido, na medida em que, dentro da evolução referida, a crise é apresentada como um desvio ou perigo do curso natural do desenvolvimento, que deve ser cuidado para a retomada da ordem natural (social). Nesse sentido, na óptica da saúde, a crise que caracteriza a "fase adolescente", em forma de sintomas típicos - síndrome normal da adolescência/síndrome da adolescência normal -, na interpretação de LUZ, 1988, poderia ser assim entendida:

"... essa manifestação maior ou menor de sintomas nada mais são que a expressão de desvios que se consideram patológicos (grifo nosso) e que estes supõem, portanto, um estado padrão normativo, uma Ordem reguladora. Nesse sentido, as categorias de 
Normal e Patológico, e sua identificação relativa contemporânea ancoram-se nas categorias de ORDEM (natural, social) e de EVOLUÇÃO (progresso)". (p.111)

Do ponto de vista antropológico, VELHO (1985), estudando comportamentos desviantes, considera que a idéia de desvio, de um modo ou de outro, "implica a existência de um comportamento médio ou ideal, que expressaria uma harmonia com as exigências do funcionamento do sistema social. Mesmo quando se encontram posições mais relativistas, permanece o problema ... "(p.17)

Mais adiante, revela que:

"É possível perceber como os estudos sobre comportamento desviante oscilam entre um psicologismo e um sociologismo. A dificuldade consiste numa visão estanque e fracionada do comportamento humano que transforma a realidade individual em algo, em princípio, independente da sociedade e da cultura - visão deformada e incompleta da atividade humana. Ou se cria uma individualidade pura, uma essência defrontando-se com o meio ambiente exterior, de outra qualidade, ou então, um fato social puro, também todo poderoso, que paira sobre as pessoas. O que se confirma é que posições aparentemente divergentes apresentam premissas comuns que vão dirigir todo o encadeamento dos raciocínios posteriores. Basicamente, é a dicotomia Indivíduo $X$ Sociedade/Cultura é que determina esses caminhos". (p.19)

Velho, ao contrário dessas idéias dominantes, encara o "desviante como o indivíduo que não está fora de sua cultura, mas que faz uma leitura divergente." (p.27)

Por essas colocações, a apresentação da "adolescência" no paradigma biomédico como uma fase crítica, crucial, traduzindo-se em forma de sintomas que compõem a síndrome normal da adolescência/síndrome da adolescência normal, revela a ambigüidade do termo crise no contexto em análise por várias razões que ora apresentamos:

1ª) O autor dessa expressão - Maurício KNOBEL, 1981, utiliza como título do capítulo em que desenvolve a sua concepção, a expressão "Síndrome da Adolescência Normal" e no subtítulo específico em que descreve a síndrome, a denominação "Síndrome Normal da Adolescência".

A colocação do termo normal, ora adjetivando a síndrome, ora adjetivando a adolescência já suscita dúvidas quanto a quê se refere a normalidade, se à síndrome ou à adolescência. Revelaria este fato uma dificuldade por parte do próprio autor na definição do objeto e suas implicações? Ou para ele a colocação seria indiferente, já que o sentido seria o mesmo? Ou seja, os termos Síndrome e Adolescência seriam termos equivalentes? 
No nosso entender, isso significaria patologizar a Adolescência, de antemão. De qualquer forma, o próprio emprego dos termos síndrome e normal, juntos numa mesma expressão, revela a incoerência na própria denominação - contraditória, dado que a palavra síndrome já nos remete ao patológico, entendido no contexto médico como um conjunto de sintomas/sintomatologia, portanto associado à noção de doença, desvio; na concepção paradigmática médico-biológica ou biomédica; adjetivar um termo - cujo significado é essencialmente patologizante - com outro que lhe é contrário/antagônico - o de normal é, no mínimo, paradoxal.

Entretanto, o próprio autor explicita o fundamento dessa expressão, ao dizer: "Penso que a estabilização da personalidade não se consegue sem passar por um certo grau de conduta "patológica" que, conforme o meu critério, devemos considerar inerente à evolução normal desta etapa da vida" (p.27); e, mais adiante, reconhece:

"Deliberadamente aceito a contradição que significa o associar síndrome que implica entidade clínica, com normalidade, que significaria estar fora da patologia. Entretanto, 0 convívio social e nossas estruturas institucionais fazem-nos ver que as normas de conduta estão estabelecidas, manejadas e regidas pelos indivíduos adultos da nossa sociedade. É sobre esta intercorrelação de gerações, e desde o ponto de vista regente e diretivo, que podemos, creio eu que devemos, estar capacitados para observar a conduta juvenil como algo que aparentemente é semi-normal e semi-patológico (nossa ênfase), mas que, entretanto, frente a um estudo mais objetivo, desde o ponto de vista da psicologia evolutiva e da psicopatologia, aparece realmente como algo coerente, lógico e normal"(p.29).

Essa forma de entendimento parte de um pressuposto que dissocia o indivíduo e sociedade; ao mesmo tempo, parte da noção de natureza adolescente que, por seu processo evolutivo uno, único, traz implícita a idéia contraditória de uma pureza imanente e, ao mesmo tempo, a de uma natureza corruptível do sujeito (adolescente). Este, ao tomar contato com o mundo adulto (sociedade), sob forma de convívio social (segundo o autor) e esse mundo adulto (que representa uma outra geração), sob cuja responsabilidade está o estabelecimento/reprodução de normas de conduta - entraria em crise (conflito de gerações), podendo resultar em patologização de condutas/sujeitos. Em outras palavras, dentro dessa concepção, o social seria o agente etiológico da crise?

Essa justificativa apresentada reforça a nossa leitura de que o autor parte da noção do patológico para tentar chegar à idéia do normal, porém sua referência permanece no primeiro, ao tomar como pressuposto que a passagem por um certo grau de conduta patológica é inerente à evolução normal para se alcançar a estabilização da personalidade. Com isso, fica explicitada a idéia de que a adolescência se caracteriza por um certo grau de conduta patoló- 
gica, que, ao mesmo tempo, é considerada normal pelo citado autor, o qual, de antemão, procede a uma classificação do que considera normal e patológico, em termos de condutas.

Estamos nos detendo na análise da Síndrome Normal da Adolescência/Síndrome da Adolescência Normal pelo fato de que ela está presente em grande parte da literatura sobre a Adolescência e em propostas de intervenção em nível de América Latina, como o modo de enxergar a adolescência como fase crítica, o que nos leva a tomá-la como modelo exemplar, segundo a lógica paradigmática de Kuhn.

Retomando o nosso raciocínio,

$2^{a}$ ) A primeira razão e os argumentos apresentados pelo autor da expressão permitem reforçar a ambigüidade do termo crise: se de um lado leva à interpretação de uma fase normal, dentro da seqüência evolutiva do desenvolvimento humano, em que os sujeitos considerados "adolescentes" (dos 10 aos 20 anos), enfrentariam/vivenciariam a crise, como inerente à "fase", por outro lado permite interpretar a própria "fase" como patológica/desviante da norma, ou seja, com isso opera-se a patologização da adolescência como tal.

Em outras palavras, não sabemos, ao certo, se o autor quis se referir à irracionalidade atingindo sujeitos dentro da racionalidade evolutiva, ou à idéia de a própria "fase" ser uma irracionalidade dentro da racionalidade evolutiva/natural do processo de desenvolvimento, que ameaçaria a restauração/retomada do curso racional da Ordem natural (social). Tudo nos leva a supor que ambas as idéias estão presentes na concepção de síndrome, que corresponde à crise - situada na área instituída como psicológica operando-se, com isso, o binômio a que se refere AYRES (1990), de universalização fenomênica-individualização (singularidade interpretativa do fenômeno), que conduz a estratégias de intervenção enfatizando indivíduos, em lugar de grupos sociais, para o reconhecimento (nos indivíduos) da intensidade dos sintomas que integrariam a Síndrome e que correspondem à área dos comportamentos humanos, nessa fase.

Knobel descreve a sintomatologia que integra essa síndrome:

a) Busca de si mesmo e da identidade: dentro de uma linha de explicação do desenvolvimento intra-individual, do processo psicológico considerado como um continuum, o autor assinala que essa "fase" deve ser vista, não só como "preparação para a maturidade, mas em termos de momento atual do desenvolvimento e do que significa o ser humano nesta etapa da vida". Apresenta o reconhecimento da identidade desse momento evolutivo, tentando observar "quais são as características fundamentais que aparecem neste período vital", como sua posição em relação a esse sintoma. Em seguida, numa linha de análise psicodinâmica - (instância intra-psíquica egóica) descreve a evolução psicossexual 
até chegar a uma "verdadeira cristalização do árduo processo de individualizacão, que seria uma das funções essenciais desta etapa da vida. A criança entra na adolescência com dificuldades, conflitos e incertezas que se magnificam neste momento vital, para sair em seguida à maturidade estabilizada com determinado caráter e personalidade adultos (nossa ênfase). Consegue-se o que Erikson definiu como uma "entidade egóica", uma entidade pessoal, e o que Nixon denominou a "auto-cognição" (...) - é o conhecimento da individualidade biológica e social, do ser psicofísico em seu mundo circundante, que tem características especiais em cada idade evolutiva. A conseqüência final da adolescência seria um conhecimento de sí mesmo como entidade biológica no mundo, o todo biopsicossocial de cada ser nesse momento da vida. Ao conceito do self como entidade psicológica, une-se o conhecimento do substrato físico e biológico da personalidade. $O$ corpo e o esquema corporal são duas variáveis intimamente interrelacionadas que não devem desconhecer-se na equação do processo de definição de si mesmo e da identidade..." (p.30).

O autor prossegue em relação ao processo de evolução da identidade adolescente, em que "dentro do continuum de sua identidade, os elementos biológicos introduzem uma modificação irreversível" (p. 36) - origem dos lutos (perda do corpo infantil, do papel e identidade infantis e luto por esses pais da infância a quem tanto se necessitava e dos quais se podia depender).

Nesse desenvolvimento, revela-se a tradição biológica da Psicologia, em que o indivíduo é considerado um organismo que interage no meio físico, sendo que os processos psicológicos (o que ocorre dentro dele) são assumidos como causa, ou uma das causas que explicariam o seu comportamento. Ou seja, "para compreender o indivíduo, bastaria conhecer - que ocorre dentro dele, quando ele se defronta com estímulos do meio", parafraseando LANE, 1984. Esta autora faz uma leitura crítica desse tipo de abordagem, argumentando que:

“...o homem fala, pensa, aprende e ensina, transforma a natureza; o homem é cultura, é história. Este homem biológico não sobrevive por si e nem é uma espécie que se reproduz tal e qual, com variações decorrentes de clima, alimentação, etc. $O$ seu organismo é uma infra-estrutura que permite o desenvolvimento de uma super-estrutura que é social e, portanto, histórica. Esta desconsideração da Psicologia em geral, do ser humano como produto histórico-social, é que a torna, se não inócua, uma ciência que reproduziu a ideologia dominante de uma sociedade, quando descreve comportamento baseada em freqüências, tira conclusões sobre relações causais pela descrição pura $e$ simples de comportamentos em situações dadas."(p.12) 
Prosseguindo em seu raciocínio, acrescenta: "Na medida em que o conhecimento positivista descrevia comportamentos restritos no espaço e no tempo, sem considerar a interrelação infra e superestrutural, estes comportamentos, mediados pelas instituições sociais, reproduziam a ideologia, em termos de freqüência observada, levando a considerálos como "naturais" e, muitas vezes, "universais". A ideologia, como produto histórico que se cristaliza nas instituições, traz consigo uma concepção de homem necessária para reproduzir relações sociais, que por sua vez são fundamentais para a manutenção das relações de produção da vida material da sociedade como tal". (p.13)

Nesse contexto, a autora localiza a Psicologia, em sua origem biológica naturalista, que se ateve apenas na descrição, seja macro ou microssocial, das relações entre os homens e das instituições sociais, sem considerar a sociedade como produto histórico-dialético, não conseguindo, por conseguinte, captar a mediação ideológica. Com isso, limitou-se a reproduzí-las como fatos inerentes à "natureza" do homem. Nesse sentido, o comportamento humano é entendido como decorrente de um organismo fisiológico que responde a estímulos, esquecendo-se de que o homem, junto com outros, ao transformar a natureza, se transforma ao longo da história. Ao finalizar sua análise em relação ao que nos interessa nesse momento, Lane assim se expressa:

"Se a Psicologia apenas descrever o que é observado ou enfocar o Indivíduo como causa e efeito de sua individualidade, ela terá uma ação conservadora, estatizante - ideológica -, quaisquer que sejam as práticas decorrentes. Se o homem não for visto como produto e produtor, não só de sua história pessoal, mas da história de sua sociedade, a Psicologia estará apenas reproduzindo as condições necessárias para impedir a emergência das contradições e a transformação social.

(...) Se o positivismo, ao enfrentar a contradição entre objetividade e subjetividade, perdeu o ser humano, produto e produtor da História, se tornou necessário resgatar o subjetivismo, enquanto materialidade psicológica. A dualidade físico X psíquico implica uma concepção idealista do ser humano, na velha tradição animística da psicologia, ou então caímos num organicismo onde homem e computador são imagem e semelhança um do outro. Nenhuma das duas tendências dá conta de explicaro homem criativo e transformador. Tornou-se necessária uma nova dimensão espaço-temporal para se apreender o Indivíduo como um ser concreto, manifestação de uma totalidade histórico-social..."(p.15)

Por essas análises de Lane, dá para perceber que tanto a psicologia como a biologia, estancando o movimento, escamoteando a contradição e impedindo a superação dialética, conforme entende CIAMPA, 1984. 
Complementando essa idéia, CASTRO E ARAÚJO (1994), integrando a vertente crítica da Psicanálise que se propõe a repensar/reinterpretar os seus conceitos básicos, referem-se ao fato de que as idéias de permanência, unidade e similaridade, denotadas pelo termo IDENTIDADE, foram abaladas pela Psicanálise, pois o conceito de inconsciente vem perturbar o caráter unitário do psiquismo. A noção de identificações múltiplas de Freud: "não sabemos, no momento em que falamos, quem está falando e por que falamos dessa maneira, já que somos uma pluralidade de pessoas psíquicas ou que o eu é um terreno por onde transitam múltiplos visitantes" abala esse conceito. Daí também, segundo os autores, "o estilhaçamento da bela unidade do indivíduo, daí a ilusão da identidade pessoal." (p.17)

Prosseguindo ainda na análise dos sintomas que compõem o quadro da Síndrome normal da Adolescência, desenvolvida por KNOBEL (1981), temos:

b) Tendência grupal - é apresentado como um recurso a que o indivíduo, na busca da identidade adolescente, procura "como comportamento defensivo à busca de UNIFORMIDADE, que pode proporcionar segurança e estima pessoal" (p.36), daí a inclinação às regras do grupo em relação em relação as modas, vestimenta, costumes, preferências de todos os tipos, etc. Ao mesmo tempo, Knobel assinala que as atuações do grupo representam a oposição às figuras parentais e uma maneira ativa de determinar uma identidade diferente da do meio familiar", representando, nesse sentido, "um reforço muito necessário para os aspectos mutáveis do ego que se produzem neste período da vida".

Mais adiante, assinala que o fenômeno grupal facilita a conduta psicopática normal no adolescente. As razões apresentadas são da mesma natureza do anterior, ou seja o psicodinamismo do desenvolvimento individual, portanto, generalizando e universalizando a tendência grupal no processo de evolução natural. Com isso, deixa de lado a interpretação histórico-social que explica que o ser humano se constroi nas e pelas relações sociais, as quais permitem, ao lado da reiteração/reprodução de valores dominantes, também a afirmação positiva de um novo modo de ser/viver/existir, que, segundo o olhar dominante na sociedade, poderia transparecer como transgressão/subversão à ordem social, enfim, um comportamento desviante.

Coerentemente com sua linha de análise, Knobel assinala esse sintoma como conduta psicopática normal no adolescente, como aquela esperada na fase, porém que, em outra fase ou melhor, persistindo em fase posterior do desenvolvimento seria considerada uma conduta psicopática, segundo o que pudemos interpretar da ambigüidade já referida anteriormente. 
c) Necessidade de intelectualizar e fantasiar - $O$ autor, continuando na mesma linha, atribui essa necessidade como mecanismo de compensação frente às perdas que ocorrem dentro de si mesmo e, ao mesmo tempo, como mecanismos defensivos, enfatizados por Anna FREUD (1969).

Prosseguindo sua explicação psicodinâmica, apresenta os outros sintomas que integram a Síndrome Normal da Adolescência/Síndrome da Adolescência Normal, sobre os quais não nos deteremos por caberem interpretações na mesma linha até aqui realizadas, o que tornaria a análise assaz repetitiva.

Fundamentalmente, algumas noções básicas chamam atenção na concepção de Síndrome Normal da Adolescência/Síndrome da Adolescência Normal, razão pela qual as apresentamos abaixo:

1) A concepção psicodinâmica do processo de desenvolvimento, como processo natural, evolutivo;

2) A noção de "adolescência" como fase, ao mesmo tempo natural/normal e patológica, no sentido de contraditória/ambígüa, decorrente da consideração de certos fenômenos evolutivos nela observados como característicos da fase e que, deslocados para/ ou persistindo em outras posteriores, corresponderiam a um quadro patológico.

3) Explicação do comportamento adolescente, assim como de outras "fases" segundo leis internas do psicodinamismo - movimento de dentro para fora, como respostas a estímulos externos, isto é, determinação das manifestações fenomênicas localizada no nível intra-psíquico, anterior/ acima ao/do processo das relações sociais.

4) Relacionada aos anteriores, verificamos a dissociação operada entre indivíduo e sociedade, como duas entidades distintas até o término da "adolescência", passandonos a seguinte idéia: ao mesmo tempo que o desenvolvimento humano até a "adolescência" seria excluído/abstraído da sociedade, como se ocorresse ao largo do processo sócio-histórico, ao mesmo tempo apresenta a sociedade, na figura de mundo adulto, como um corpo estranho, um ambiente natural (social), separado, onde se localizaria o elemento patológico - irracional -, que se apresenta como ameaça à racionalidade do processo que seria, em si, pautado na regularidade, harmonia, coerência e continuidade.

5) Como resultado da relação dicotômica e oposta: "adolescente" $x$ "mundo adulto" (sociedade) - os fenômenos observados na fase em estudo seriam considerados semi-normais ou semi-patológicos, como se estivessem localizados na intersecção do normal e do patológico, bastando, assim, um estímulo externo em maior ou menor intensidade para defi- 
nir o seu desenlace em termos de um ou de outro (patológico ou normal). De qualquer forma, fica evidente o raciocínio desenvolvido pelo autor na adoção da expressão da Síndrome - ele parte do Patológico para o Normal, coerentemente com a análise efetuada por LUZ (1992), para quem as ciências "humanas", que emergiram no movimento de constituição da racionalidade da Ciência moderna positiva (em particular a medicina e sociologia, e aqui acrescentamos a psicologia), partem do patológico para o normal, portanto, desenvolvem análises, tendo como referência o patológico, seja tendo em vista a cura ou a prevenção de problemas (estes abstraídos/desvinculados de seu contexto).

Essa noção de adolescência patológica pode ser melhor visualizada nas palavras de WINNICOTT(1965) que afirma: "A cura para a Adolescência é a passagem do tempo, fato que tem muito pouco significado para o Adolescente" (p.40).

Após um estudo mais atento das noções presentes na expressão da referida síndrome, temos, para nós, que o objeto de estudo são os comportamentos sociais, que, no entanto, ficam velados/encobertos/ocultos, pela forma de desenvolvimento por parte do autor, que os abordou no nível de sua determinação (psicogenética), enfatizando um tipo de explicação psicologizante e biologizante, que conduz/leva à idéia de um processo natural que caminha, "pari passu“, paralelo ao processo sócio-histórico; dá a idéia de que o processo de desenvolvimento infantil e "adolescente" se refere à preparação (socialização) de indivíduos para sua integração na sociedade, numa espécie de torná-los aptos ("prontos", na linguagem pedagógica no sentido de prontidão) para integrarem o mundo adulto (sociedade), como se, até então, todo o processo corresse ao largo da sociedade, a qual se manteria em compasso de espera, aguardando indivíduos com determinados perfís, construídos/fabricados/ serializados/uniformizados, segundo a norma (natural-social) para a sua inserção social no sentido de incorporação à força de trabalho, ou para sua marginalização/exclusão, no caso daqueles que fugissem/diferenciassem do padrão da ordem (natural-social) instituída.

Essa nossa leitura encontra apoio em CASTORIADIS (1992) que afirma:

"Psique não é o indivíduo: a psique torna-se indivíduo unicamente na medida em que ela sofre um processo de socialização (sem o qual, aliás, nem ela, nem o corpo que ela anima poderiam sobreviver sequer por um instante).

(...) Esse próprio processo, sem dúvida alguma, é uma atividade social-e, como tal, é necessariamente também sempre mediatizado por indivíduos, nomeadamente identificáveis como, por exemplo, a mãe - porém, não somente. Não somente esses indivíduos já são sempre socializados, mas o que transmitem ultrapassa-os de muito: sem entrar em detaIhes, e para designar apenas um aspecto, digamos que tais indivíduos fornecem os meiose 
os modos de acesso à totalidade do mundo social a cada vez instituído, totalidade que não tem nenhuma necessidade de possuir efetivamente (e até de fato, não poderiam possuir 'efetivamente'). (p.57).

(..) Resumindo, digo que a socialização dos indivíduos - processo ele mesmo socialmente instituído, e a cada vez diferentemente - abre acesso a um mundo de significações imaginárias sociais.

(...) Essas significações existem efetivamente (social-historicamente) sendo instituídas. Não são redutíveis à transubstanciação das pulsões psíquicas: a sublimação é a face psíquica do processo, cuja face social é a fabricação do indivíduo (grifo nosso). E essas significações não são evidentemente redutíveis à racionalidade, qualquer que seja a extensão dada ao sentido desse termo" (p.58).

Reafirmada com a contribuição de Castoriadis, essa dissociação: indivíduo x sociedade, que corresponde à visão decorrente da racionalidade da Ciência moderna positiva, legitima, sob o manto da "ciência", um discurso ideológico sobre o processo de desenvolvimento humano, portanto, - da existência humana -, abstraindo-o de sua materialização em contextos sócio-históricos determinados, considerando-os como essência/natureza humana em si, que se realiza/atualiza/evolui, apesar e independente da realidade concreta. Naturalizado e neutralizado o conhecimento sobre o existir humano, este (conhecimento) dissimula a existência de indivíduos reificados/objetivados, segundo a ordem capitalista - "formados" /"educados"/ "desenvolvidos"/ "socializados", em conformação a uma norma/padrão (social), visando a sua "integração"/ "submissão" às leis que regem a Ordem (natural-social) - hierarquizada - definidora das posições/lugares de seus membros, assim como dos comportamentos sociais correspondentes. Desta forma, reafirmase a ilusão de um processo igualitário, a que todos os homens estariam submetidos em idênticas condições (como se fossem intercambiáveis entre si), que dá como resultado seres humanos diferentes, individualizados, em posições sociais assimétricas, em função de suas capacidades inatas, próprias de cada indivíduo, ou seja, da capacidade de resposta de cada um aos estímulos provenientes do mundo adulto (sociedade). A explicação, então, estaria em cada indivíduo e não na sociedade em que nasce, já numa dada condição sócio-histórica, anterior à sua própria existência, e que define as possibilidades e dificuldades de seu processo de "desenvolvimento" numa dada direção.

A idéia de que a crise adolescente está nele (sujeito) ou na "fase", independentemente dè considerar-se o mundo "adulto" (sociedade) como o agente patológico, segue o mesmo raciocínio da história natural da doença, que pressupõe um curso natural, com várias 
fases, inclusive a que antecede o processo mórbido no próprio homem (hospedeiro). Tal fase, anterior à manifestação do problema, apresenta uma condição natural existente - a presença do agente etiológico (agente mórbido - drogas, atividades sexuais sem proteção, cigarros, álcool, etc.), a presença de um hospedeiro (no caso o "adolescente"/jovem) e a presença de um ambiente (físico, social - periferia urbana, pobreza, ambiente famíliar, grupo de pares, etc), em estado de interação e equilíbrio (tríade ecológica), até que, por uma ação de um estímulo externo, tem o seu equilibrio rompido, face a condições favoráveis para a ocorrência da patologia no homem, seja em termos de fragilidade do hospedeiro (adolescente), seja pela pressão/ força/potência do agente mórbido (drogas, atividade sexual precoce, sem os cuidados contraceptivos, comportamentos arriscados em geral), seja por condições ambientais desfavoráveis (famílias desestruturadas, pobreza, residência em periferias urbanas, falta de estudo, desemprego, ociosidade, etc.). Nesse sentido, o agente mórbido, com sua potência/ força, aliado às condições ambientais favorecedoras, em face de uma situação de fragilidade do indivíduo/hospedeiro/adolescente - insegurança, problema agudo que esteja atravessando, necessidade de afirmação mediante assunção de comportamentos que contrariem a norma dos "adultos", conflitos familiares, etc. - portanto, vulnerável/suscetível, desencadeia o processo mórbido no próprio indivíduo, que pode se dar durante a adolescência ou em idades posteriores [gravidez precoce, drogadição, acidentes, homicícios, suicídios - no próprio período da "adolescência" -, ou mais tarde, quando adulto, em forma de câncer nos pulmões (para os fumantes), cirroses hepáticas (para os consumidores de álcool), problemas de hipertensão, cardiopatias, etc.] e que podem redundar em agravamento do processo que pode resultar em morte (de si próprio ou de terceiros), ou invalidez (idem), delinqüência, prostituição, abortos, alcoolismo, dependência a drogas, maternidade precoce, filhos maltratados, etc.

Esse raciocínio, como já foi descrito anteriormente no paradigma médico-biológico ou biomédico, leva a circunscrever o problema no indivíduo (hospedeiro) portador do mesmo, e nele se fixar como causa e responsável pelo próprio problema, abstraindo-o do contexto em que se originou o processo, e nele aplicando as medidas terapêuticas, portanto, visualizando como um processo que se inicia e termina no indivíduo (adolescente). Logo, o alvo de todo o trabalho é o adolescente, enquanto indivíduo, seja em termos promocionais, preventivos ou curativos.

O importante nesse raciocínio é que, a partir da contabilidade que se faz sobre os problemas mais freqüentes em adolescentes, que a estatística possibilita em termos de coeficientes (números) e conhecendo-se a história/processo natural (social) de cada patologia (biológica-social), é possível, a partir das características, atributos mais freqüentes dos portadores/adolescentes de cada tipo de problema, estabelecer um perfil de indivíduos que 
passam a ser considerados potencialmente doentes, desviantes. Estes resultados passam a orientar práticas promocionais, preventivas junto àqueles que se enquadram no perfil descrito, para serem objetos prioritários de atenção por parte de agentes institucionais voltados à questão do adolescente - seja do ponto de vista da saúde, da educação e/ou de outros setores, que passam a considerá-los como parte do grupo de risco - a intervenção é centrada precipuamente em ações educativas, que enfatizam a informação sobre o problema em si causas, características do problema, conseqüências - e, finalmente, cuidados para sua prevenção (modelos de comportamento social).

Ao abordar os cuidados a serem tomados, são prescritas normas de conduta, orientadas não só pelos aspectos técnicos que envolve, mas sobretudo pelas normas sociais/ morais, ditadas pela organização social (valores dominantes na sociedade), a qual norteia e define o que classifica como comportamentos saudáveis e, ao fazê-lo, explicita, também, os comportamentos nocivos/desviantes/excludentes. Dentro da liberalidade capitalista, a partir disso, na concepção do individualismo, dissimulado em forma de liberdades individuais, passa-se a responsabilizar cada indivíduo/adolescente da escolha feita entre adotar um estilo de vida saudável, que supõe comportamentos sociais adequados ànorma, ou um estilo de vida nocivo, de comportamentos arriscados à saúde (de quem?) que conduzem aos desvios.

\section{CONSIDERAÇÕES FINAIS}

O reconhecimento da concepção de adolescência/adolescente presente no discurso da Saúde Pública, de forma hegemônica, como aquela enraizada no paradigma biomédico/ médico-biológico, leva-nos à presença de um projeto pedagógico (Projeto Social), que dá os contornos, o conteúdo moral, socialmente construído, que disciplina/dociliza os corpos para manter uma dada ordem no pensar e agir "adolescente" e, assim, possibilita prevenir os desvios durante o curso natural/social , que ruma para uma dada concepção de maturidade, quer dizer, a um dado perfil de adulto necessário para a continuidade da ordem natural-social instituída. Para isso, são importantes as formas de abordagem dos sujeitos em questão, em função das características inerentes a essa fase, descritas segundo regras do conhecimento "científico", portanto, um conhecimento racionalmente construído a respeito do real. Desta forma, práticas pedagógicas que atendam às necessidades peculiares da fase - fartamente estudadas e definidas por especialistas - devem ser cuidadosamente selecionadas e postas em prática, especialmente aquelas que propiciem, por exemplo, a participação dos sujeitos (adolescentes/jovens), a convivência com os pares de forma saudável, relações mais horizontalizadas entre adultos e jovens, atividades que valorizem a auto-estima, a afirmação, a intelectualização, a fantasia, a ação, a expressão de sentimentos, etc. A concretização deste tipo de trabalho, por sua vez, requer pessoal devidamente preparado (normalizado), 
com conhecimentos e habilidades especiais, a serem desenvolvidas mediante atividades de educação continuada - cursos, treinamentos, simpósios, congressos, etc.

Tal reconhecimento, fruto de uma leitura, dentre outras possíves, alerta para a necessidade de estarmos repensando conceitos utilizados na área, muitas vezes de forma mecânica, dado que carregam pressupostos teóricos que levam a determinados tipos de práticas correspondentes, com dada direção.

\section{REFERÊNCIAS BIBLIOGRÁFICAS:}

ABERASTURY, A. \& KNOBEL, M. La adolescencia normal. Buenos Aires, Paidós; 1971.

AYRES, J.R.C.M. Adolescência e saúde coletiva: aspectos epistemológicos da abordagem programática. In: SCHRAIBER, L.B. Programação em saúde hoje. São Paulo: Editora HUCITEC; 1990. p.129-82.

CASTELLAR, C. Psicanálise e adolescência: considerações teórico-técnicas. In: CASTELLAR, C. \& FREITAS, L.A. Crise da adolescência: visão psicanalítica. Rio de Janeiro: Rocco; 1989.

CASTORIADIS, C. A instituição imaginária da sociedade. Rio de Janeiro: Paz e Terra; 1982.

CASTORIADIS, C. As encruzilhadas do labirinto, III: o mundo fragmentado. Rio de Janeiro, Paz e Terra, 1987-1992.

CASTRO, E.M. \& ARAUJO, J.N.G. Análise social e subjetividade. In: LÉVY, A. et al. Psicossociologia: análise social e intervenção. Petrópolis: Vozes; 1994 p. 15-23.

CAVALCANTI, R.C. Adolescência. In: VITIELLO, N. et al. Adolescência hoje. São Paulo: Roca; 1988 p. 5-27.

CHARLOT, B. A mistificação pedagógica: realidades sociais e processos ideológicos na teoria da educação. 2a. ed. Rio de Janeiro: Guanabara; 1986.

CHAUI, M. Conformismo e resistência. 2a. ed. São Paulo: Brasiliense; 1987 p. 30-1.

CHAUI, M. Cultura e democracia - o discurso competente e outras falas. 2a. ed. São Paulo: Moderna; 1981.

CIAMPA, A.C. Identidade. In: LANE, S.T.M. \& CODO, W., (org.) Psicologia social: o homem em movimento. 9a. ed. São Paulo: Brasiliense; 1991. p. 58-75.

COSTA, J.F. Ordem médica e norma familiar. Rio de Janeiro:Graal; 1983. 
COVRE, M.L.M. Cidadania, cultura e sujeitos. In: SPINK, M.J.; (org.) Cidadania em construção - uma reflexão interdisciplinar. São Paulo: Cortez; 1994.

DUARTE, L.F.D. Os "nervos" e a antropologia médica norte-americana: uma revisão crítica. Physis-Rev. Saúde Coletiva, 3(2):43-73,1993.

GUATTARI, F. \& ROLNIK, S. Micropolítica: cartografias do desejo. Petrópolis: Vozes; 1986.

HAMBURG, D \& HAMBURG, B. Becoming mature. Apud OPS. La Salud de los Adolescentes - un compromiso con el futuro. Washington, D.C., 1985, (OPS, Publicación Científica, 489).

KNOBEL, M. Síndrome da adolescência normal. In: ABERASTURY, A. \& KNOBEL, M. Adolescência normal. $9^{a}$ ed. Porto Alegre, Artes Médicas, 1981. p. 24- 62.

KOSIK, K. Dialética do concreto. 5a. ed. Rio de Janeiro: Paz e Terra; 1976.

KUHN, T.S. Estrutura das revoluções científicas. 3a. ed. São Paulo, Perspectiva; 1992.

LANE, S.T.M. A psicologia social e uma nova concepção do homem para a Psicologia. In: LANE, S.T.M. \& CODO, W. Psicologia social: o homem em movimento. 9a ed. São Paulo: Brasiliense; 1991; p.10-19.

LUZ, M.T. Natural, racional, social: razão médica e racionalidade científica moderna. Rio de Janeiro: Campus; 1988.

ORGANIZACIÓN MUNDIAL DE LA SALUD. Comité de Expertos de la OMS en Necesidades de salud de los adolescentes. Ginebra, 1976. Informe. Ginebra; 1977 [OMS - Serie de Informes Técnicos, 609].

ORGANIZACIÓN MUNDIAL DE LA SALUD. Conclusiones y recomendaciones de las Discusiones Técnicas sobre la Salud de los Jóvenes de la 42a Asamblea Mundial de la Salud, Ginebra, 1989.

ORGANIZACIÓN MUNDIAL DE LA SALUD. Discusiones Técnicas sobre la Salud de los Jóvenes. Asamblea mundial de la Salud, 42 Ginebra 1989, mayo.Documento Básico. Ginebra, 1989.

ORGANIZACIÓN MUNDIAL DE LA SALUD. Grupo de Estudio de la OMS acerca de los Jóvenes y la "Salud para Todos en el año 2000" Ginebra, 1984. Informe: La salud de los jóvenes: un desafío para la sociedad. Ginebra, 1986 [OMS- Serie de Informes Técnicos, 731]. 
OSÓRIO, L.C. Adolescente hoje. Porto Alegre: Artes Médicas; 1991.

PINTO, Á.V. Ciência e existência: problemas filosóficos da pesquisa científica. $2^{\mathrm{a}}$ ed. Rio de Janeiro: Paz e Terra; 1979.

SALTALAMACCHIA, H.R. La juventud en la época moderna: un análisis conceptual. Puerto Rico, Cuadernos CIJUP; 1990 (Colección Ensayos).

TORRES - RIVAS, E. Introducción al análisis comparativo de la juventud. In: TORRESRIVAS, E. et al. Escépticos, narcisos, rebeldes - 6 estudios sobre la juventud. San Jose: FLACSO/CEPAL, VARITEC; 1989.

USCÁTEGUI, R.G. Desarrollo psicosocial: perspectivas vigentes. In: ORGANIZACIÓN PANAMERICANA DE LA SALUD. Crecimiento y desarrollo - hechos y tendencias. Washington, D.C.; 1988; p. 351-65. [Publicación Científica, 510].

VELHO, G. O estudo do comportamento desviante: a contribuição da Antropologia Social, In: VELHO, G.,(org.) Desvio e divergência: uma crítica da patologia social. $5^{\mathrm{a}}$ ed. Rio de Janeiro: Jorge Zahar; 1985; p. 11-28.

VICUÑA, J.R. La salud del adolescente y del jóven en América Latina y el Caribe. Bol. Ofic. Sanit. Panam. 83:295-309, 1977.

WINNICOTT, D. W. Adolescence: struggling through the doldrums. In: —— The family and individual development. London: Tavistock Publication, 1965, apud ABERASTURY, A. et al. 2a. ed. Porto Alegre: Artes Médicas; 1993.

\begin{abstract}
Summary: The present paper is part of the $\mathrm{PhD}$ dissertation presented and defended in the Faculty of Public Health-USP in 1995. It is a theorical piece of work in the field of Social Sciences. It aims at a critical analysis of the knowledge produced and used in the health area that has hegemonically directed the practice with adolescents uncovering the concept of adolescent/adolescence present in the Public Health discourse. The adopted conception is recognized by means of a historic deconstruction and reconstruction of the discourse under study with the use of the Social History research tools. Such conception represents the biomedical paradigm that has predominantly guided the production of knowledge and corresponding practices in the areas.
\end{abstract}

Key words: adolescent/adolescence; Public Health; discourse; social sciences 